\title{
THE EFFECTS OF NEW 1,3-THIAZOLIDINE-4-ONES WITH PYRRAZOLONE SCAFOLD ON MOTOR FUNCTION IN MICE
}

\author{
MARIA APOTROSOAEI ${ }^{1}$, IOANA MIRELA VASINCU ${ }^{1 *}$, SANDRA MĂDĂLINA CONSTANTIN ${ }^{1}$, \\ ANDREEA-TEODORA IACOB ${ }^{1}$, GEORGIANA-ROXANA TAUȘER ${ }^{1}$, DAN LUPAȘCU ${ }^{1}$, \\ CĂTĂLINA-ELENA LUPUȘORU ${ }^{2}$, LENUȚA PROFIRE ${ }^{1}$ \\ l "Grigore. T. Popa" University of Medicine and Pharmacy Iași, Faculty of Pharmacy, Department of Pharmaceutical Chemistry, \\ Universității Street, no. 16, 700115, Iași, Romania \\ 2 "Grigore. T. Popa" University of Medicine and Pharmacy Iași, Faculty of Medicine, Department of Pharmacology, Clinical \\ Pharmacology and Algesiology, Universității Street, no. 16, 700115, Iași, Romania
}

*corresponding author: ioana-mirela.vasincu@umfiasi.ro

Manuscript received: October 2018

\begin{abstract}
The aim of this study was to investigate the effects of new 1,3-thizolidine-4-ones with pyrazolone scaffold (7a-m) on motor function in mice, using RotaRod performance and spontaneous locomotor activity tests. The toxicity screening of these compounds was also performed. The results of RotaRod performance test showed that the compounds don't have appreciable negative influence on neuromuscular activity, the recorded values being comparable with those of phenazone and control, so it could be appreciated that these compounds don't have neurotoxic effects. In the case of spontaneous locomotor activity test, the most intense negative effect was observed for $7 \mathbf{j}\left(3-\mathrm{OH}, 4-\mathrm{OCH}_{3}\right)$, for which the horizontal and vertical movements were lower than phenazone and control at all three-time intervals $(1 \mathrm{~h}, 2 \mathrm{~h}, 4 \mathrm{~h})$. For other derivatives no appreciable negative effect on spontaneous locomotor activity was observed. Referring to the toxicity degree, all tested compounds showed lower toxicity in reference with phenazone, which supports the favourable influence of 1,3-thiazolidine-4-one moiety on pyrazolone scaffold.
\end{abstract}

\section{Rezumat}

Scopul acestui studiu a fost de a evalua efectele unor noi derivați de 1,3-tiazolidin-4-onă cu structură pirazolonică (7a-m) asupra funcției motorii la şoarece, utilizând testul tijei rotante (RotaRod) şi testul activității locomotorii spontane. S-a determinat totodată şi gradul de toxicitate al compușilor testați. Rezultatele testului tijei rotante au arătat că derivații studiaţi nu au o influență negativă apreciabilă asupra activității neuromusculare, valorile înregistrate fiind comparabile cu cele pentru fenazonă și lotul martor, putându-se astfel aprecia că derivații nu au efecte neurotoxice. În cazul activității locomotorii spontane, cel mai intens efect negativ a fost observat pentru compusul $\mathbf{7 j}\left(3-\mathrm{OH}, 4-\mathrm{OCH}_{3}\right)$, pentru care mișcările în plan orizontal și vertical au fost mai reduse comparativ cu fenazona și lotul martor, la toate cele trei intervale de timp studiate (1 oră, 2 ore, 4 ore). Pentru ceilalți derivați nu s-a observat un efect negativ apreciabil asupra activităţii locomotorii. Referitor la gradul de toxicitate, rezultatele au arătat că toți derivații studiați sunt mai puțin toxici comparativ cu fenazona, ceea ce susține influența favorabilă a ciclului de 1,3-tiazolidin-4-onă asupra structurii pirazolonice.

Keywords: 1,3-thiazolidin-4-one, pyrazolone scaffold, motor function, toxicity degree

\section{Introduction}

The pyrazolone scaffold is known mainly for analgesic, antipyretic and anti-inflammatory effects and some of its derivatives, such as phenazone, dipyrone, propyphenazone and aminophenazone are important therapeutic agents [1]. It is also known that the therapeutic use of these agents is often limited by their side effects, especially on haematological and gastrointestinal level. In order to improve the safety and effectiveness of pyrazolone derivatives, the researchers have focused their work to modulate this scaffold [1]. As a result, many pyrazolone derivatives have been developed and evaluated for other important effects such as antioxidant [2], antimicrobial [3] and antitumour [4].
On the other hand, the 1,3-thiazolidine-4-one ring gained much interest in the last years in the field of medicinal chemistry [5]. 1,3-thiazolidine-4-one derivatives were evaluated for antibacterial [5], antifungal [6,7], antioxidant [8], cytotoxic [9], antiinflammatory [10], antiviral [11] and anti-diabetic [12] effects.

Based on phenazone, our research group has synthesized new 1,3-thiazolidin-4-one derivatives whose synthesis was reported in our previous paper [13]. These derivatives showed improved antioxidant effects in reference with phenazone [13]. To continue our research, in this paper we present the evaluation results of these compounds for their effects on motor activity in mice using RotaRod test and assessment of spontaneous 
locomotor activity. These tests are non-invasive tools and are usually used in preclinical evaluation of the drugs [14].

\section{Materials and Methods}

Materials

The study was performed using adult Swiss mice weighing 22 - $35 \mathrm{~g}$ (Cantacuzino Institute, Bucharest, Romania). The animals were housed at $23 \pm 2^{\circ} \mathrm{C}$, humidity of $40-60 \%$, with natural day-night cycle, having ad libitum access to food and water. The mice were kept fasting for $24 \mathrm{~h}$ before the experiment and were randomized into groups with 6 mice for each group. Thirteen new 1,3-thiazolidine-4-one derivatives based on pyrazolone scaffold (7a-m) were included in the study. The tested derivatives were synthesized starting from different substituted aromatic aldehydes (1a-m), ethyl 3-aminopropionate hydrochloride (2) and mercaptoacetic acid (3), when ethyl 3-(2-aryl-4oxo-thiazolidin-3-yl)-propionate derivatives (4a-m) have been obtained. These intermediaries were transformed into corresponding acid derivatives (5a-m), which finally were coupled with 4-aminophenazone (6) [13] (Figure 1).

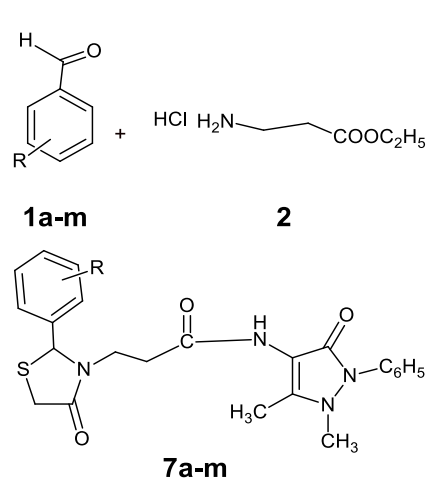

7a-m

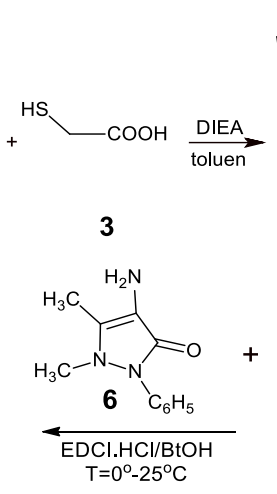

Figure 1.

The synthesis of 1,3-thiazolidine-4-one derivatives with pyrazolone scaffold (7a-m)

\section{Acute toxicity assay}

The toxicity degree of new 1,3-thiazolidine derivatives with pyrazolone scaffold (7a-m) was evaluated by determining of the lethal dose $50\left(\mathrm{LD}_{50}\right)$. The tested derivatives were orally administered (p.o.) using Tween 80 as vehicle in doses ranging between 500 $3000 \mathrm{mg} / \mathrm{kg}$ bw. The survival rate was determined at 24h, 48h, 72h, 7 days and 14 days after administration. The lethal dose $50\left(\mathrm{DL}_{50}\right)$ was determined by Karber method using the following formula [14]:

$$
L D_{50}=L D_{100}-\frac{\Sigma(a \times b)}{n},
$$

where, $a=$ the difference between two successive doses of the tested derivative; $b=$ the arithmetic average of the animals from two successive series that died; $n=$ the number of animals per group; $\mathrm{LD}_{100}=$ the $100 \%$ lethal dose.

Motor function assays

The RotaRod performance test is one of the most used tests to assess the effect of drugs on animal behaviour, providing if the tested compounds have any effects on neuromuscular coordination [15]. In this test a commercially available RotaRod Apparatus (Ugo Basile Biological Research Apparatus, Italy) was used and the study was conducted according to general protocol [16]. The RotaRod consists of a circular rod turning at a constant or increasing speed. Animals placed on the rotating rod try to remain on it rather than fall onto a platform. The drugs known to alter the neuromuscular coordination, such as the benzodiazepines, reduce the time in which the animals are able to remain on the rod. Only the mice with good locomotor activity which passed the RotaRod test, that means they were able to remain on the rod at least $60 \mathrm{sec}$, were included in the study. The effect of tested compounds (7a-m) on neuromuscular coordination and balance of the mice on the rod rotating with $15 \mathrm{rpm}$ was evaluated during $180 \mathrm{sec}$. Assessment of spontaneous locomotor activity. Spontaneous locomotor activity and exploratory behaviour of mice were monitored using the LE-8811 Actimeter (PanLAB Harvard Apparatus, Barcelona, Spain) $[17,18]$. This equipment contains three plexiglass cages (38 $\times 24 \times 21 \mathrm{~cm}$ internal dimensions), having around two-dimensional (horizontal and vertical axes) square frame connected to silent electronic counters. In the frames there are the infrared photo beams transmitters and receivers. During the test, horizontal locomotor activity (movements or stereotype movements) was determined by breaks in movement-sensitive photo beams that were then converted into locomotor activity counts, and vertical activity was recorded as the number of rearing episodes breaking the photocell beams of the upper frame. The frames are connected directly through a SeDaCom computer software, which allows easy exportation of data in a format compatible with Excel. Prior to the test, each animal was placed 
FARMACIA, 2019, Vol. 67, 2

in the centre of the arena, and the spontaneous locomotor behaviour was tracked for $5 \mathrm{~min}$. The spontaneous locomotor activity was counted at $1 \mathrm{~h}, 2 \mathrm{~h}$ and $4 \mathrm{~h}$ after administration of the tested compounds. Administration protocol of the tested compounds. The 1,3-thiazolidine-4-one derivatives with pyrazolone scaffold (7a-m) were dissolved in Tween 80 to obtain a stock solution of $10 \mathrm{mg} / \mathrm{mL}$. From the stock solutions, each tested compound was administrated orally in dose of $1 / 20 \mathrm{LD}_{50}$, in a volume of $0.1 \mathrm{~mL} / 10 \mathrm{~g}$ bw. Tween $80(0.092 \mathrm{~mL} / 10 \mathrm{~g})$ and phenazone $(56.50 \mathrm{mg} / \mathrm{kg} \mathrm{bw})$ were administrated to control and reference group respectively. The administered doses are presented in Table I.

Table I

The administrated doses ( $\mathrm{mg} / \mathrm{kg}$ bw) of tested compounds (7a-m)

\begin{tabular}{|c|c|c|c|c|c|}
\hline Group & Compound/R & Dose (mg/kg bw) & Group & Compound/R & Dose (mg/kg bw) \\
\hline 1 & $7 \mathrm{a} / \mathrm{H}$ & 84.40 & 8 & $7 \mathrm{~h} / 2-\mathrm{NO}_{2}$ & 86.00 \\
\hline 2 & $7 \mathrm{~b} / 4-\mathrm{Cl}$ & 84.00 & 9 & $7 \mathrm{i} / 3-\mathrm{NO}_{2}$ & 83.50 \\
\hline 3 & $7 \mathrm{c} / 4-\mathrm{F}$ & 84.75 & 10 & $7 \mathrm{j} / 3-\mathrm{OH}, 4-\mathrm{OCH}_{3}$ & 87.50 \\
\hline 4 & $7 \mathrm{~d} / 4-\mathrm{Br}$ & 86.00 & 11 & $7 \mathrm{k} / 4-\mathrm{OH}, 3-\mathrm{OCH}_{3}$ & 90.00 \\
\hline 5 & $7 \mathrm{e} / 2-\mathrm{OCH}_{3}$ & 90.50 & 12 & $7 \mathrm{l} / 4-\mathrm{CH}_{3}$ & 84.00 \\
\hline 6 & $7 \mathrm{f} / 3-\mathrm{OCH}_{3}$ & 87.50 & 13 & $7 \mathrm{~m} / 2,6-\mathrm{diCl}$ & 83.50 \\
\hline 7 & $7 \mathrm{~g} / 4-\mathrm{OCH}_{3}$ & 89.50 & 15 & Phenazone $(\mathrm{Phz})$ & 56.50 \\
\hline
\end{tabular}

The experiments were performed according to the ethics guidelines on laboratory animals studies (Law no. 206/May 27, 2004, EU/2010/63 - CE86/609/EEC) and with the agreement of the Ethic Committee for Animal Research of "Grigore T. Popa" University of Medicine and Pharmacy Iași, Romania.

Statistical analysis

The data were expressed as mean \pm standard deviation. The analysis of data was performed using SPSS 17.0 software for Windows. In order to assure normal distribution of data, ANOVA one-way analysis of variance with Tukey's Post Hoc test were used for multiple comparisons. $p$ values less than 0.05 were considered statistically significant compared to control group.

\section{Results and Discussion}

\section{Toxicity degree}

The toxicological screening highlighted that all tested derivatives (7a-m) have low toxicity, the $\mathrm{LD}_{50}$ values ranging between $1670 \mathrm{mg} / \mathrm{kg}$ bw $(\mathbf{7 m})$ and 1810 $\mathrm{mg} / \mathrm{kg}$ bw (7e) (Table II). These compounds proved to be less toxic than phenazone $\left(\mathrm{LD}_{50}=1130 \mathrm{mg} / \mathrm{kg} \mathrm{bw}\right)$ [19], which supports the favourable influence of thiazolidine-4-one moiety upon the chemical modulation of pyrazolone scaffold.

Table II

The toxicity degree ( $\mathrm{DL}_{50}$ values) of the tested compounds (7a-m)

\begin{tabular}{|c|c|c|c|c|c|}
\hline Comp. & $\mathbf{R}$ & $\left.\mathbf{D L}_{\mathbf{5 0}} \mathbf{~} \mathbf{m g} / \mathbf{k g} \mathbf{b w}\right)$ & $\mathbf{C o m p}$. & $\mathbf{R}$ & $\left.\mathbf{D L}_{\mathbf{5 0}} \mathbf{~ m g} / \mathbf{k g} \mathbf{b w}\right)$ \\
\hline $\mathbf{7 a}$ & $7 \mathrm{H}$ & 1688 & $\mathbf{7 h}$ & $2-\mathrm{NO}_{2}$ & 1720 \\
\hline $\mathbf{7 b}$ & $4-\mathrm{Cl}$ & 1680 & $\mathbf{7 i}$ & $3-\mathrm{NO}_{2}$ & 1670 \\
\hline $\mathbf{7 c}$ & $4-\mathrm{F}$ & 1695 & $\mathbf{7 j}$ & $3-\mathrm{OH}, 4-\mathrm{OCH}_{3}$ & 1750 \\
\hline $\mathbf{7 d}$ & $4-\mathrm{Br}$ & 1720 & $\mathbf{7 k}$ & $4-\mathrm{OH}, 3-\mathrm{OCH}_{3}$ & 1800 \\
\hline $\mathbf{7 e}$ & $2-\mathrm{OCH}_{3}$ & 1810 & $\mathbf{7 l}$ & $4-\mathrm{CH}_{3}$ & 1680 \\
\hline $\mathbf{7 f}$ & $3-\mathrm{OCH}_{3}$ & 1750 & $\mathbf{7 m}$ & $2,6-\mathrm{diCl}$ & 1670 \\
\hline $\mathbf{7 g}$ & $4-\mathrm{OCH}_{3}$ & 1790 & $\mathbf{P h z}$ & Phenazone & 1130 \\
\hline
\end{tabular}

\section{The RotaRod performance test}

For each tested compound (7a-m), it was recorded the time $(\mathrm{sec})$ in which the mice remained on the rotating rod. For the most compounds, the obtained values were comparable with those recorded for phenazone and control (Figure 2). A slight negative influence was observed for compounds $7 \mathbf{j}$ (3-OH, 4- $\left.\mathrm{OCH}_{3}\right), 7 \mathbf{k}\left(3-\mathrm{OCH}_{3}, 4-\mathrm{OH}\right), \mathbf{7 d}(4-\mathrm{Br})$ and $\mathbf{7 f}(3-$ $\mathrm{OCH}_{3}$ ). For these compounds the values recorded at $4 \mathrm{~h}$ after administration were $117.6 \pm 19.3(\mathbf{7 j})$, $120.0 \pm 16.2(\mathbf{7 k}), 121.7 \pm 21.7(\mathbf{7 d}), 129.8 \pm 17.7$ (7f), this being slightly lower than phenazone (158.0 $\pm 24.6)$ and control $(142.0 \pm 19.6)$ respectively. We can appreciate that the tested derivatives (7a-m), as well as phenazone, have not appreciable influence on neuromuscular activity in mice, because it was not observed the loss of equilibrium which could be associated with neurotoxic effects. No statistically significant differences $(p>0.05)$ between the tested compounds (7a-m) and phenazone and control, at all time intervals ( $1 \mathrm{~h}, 2 \mathrm{~h}, 4 \mathrm{~h}$ ), were observed. 


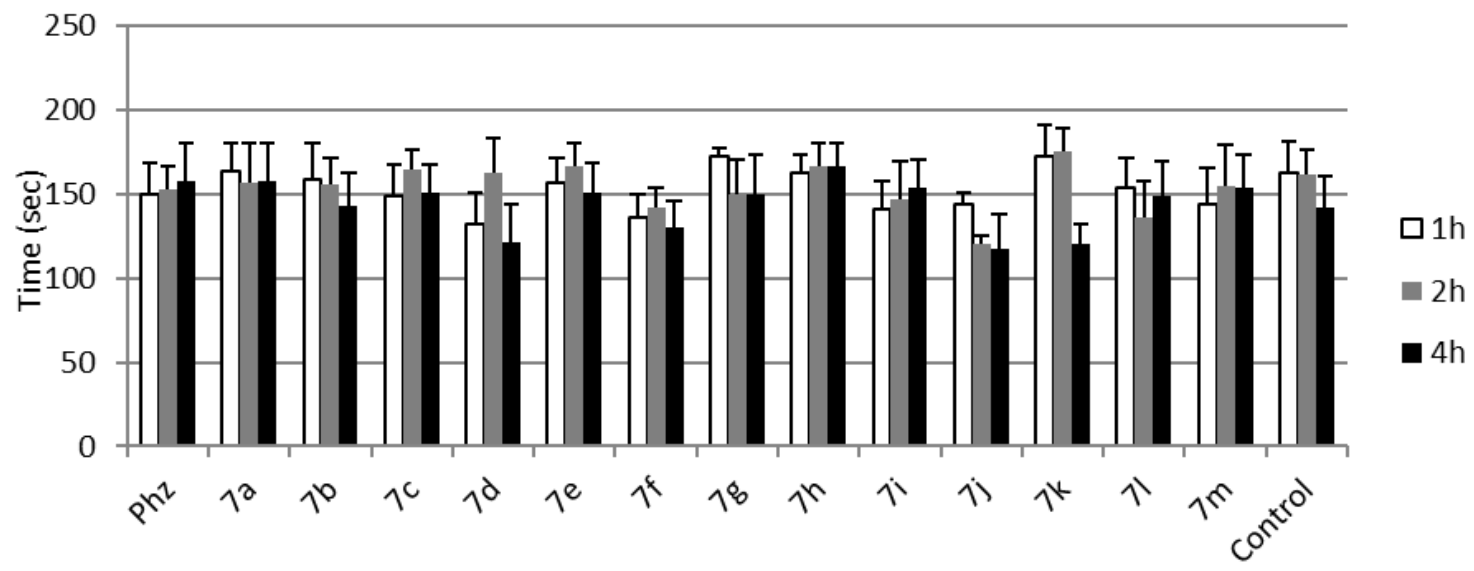

Figure 2.

The RotaRod test results recorded for the tested compounds (7a-m) in reference with phenazone (Phz) and control (Tween 80) groups

\section{Assessment of spontaneous locomotor activity}

The changes of mice behaviour were recorded as horizontal (licking of paw, cleaning of hair and of nose) and vertical movements (climbing and jumping on walls of cage), and could be associated with anxiety or depressive-like state. The results of mice behaviour at $1 \mathrm{~h}, 2 \mathrm{~h}$ and $4 \mathrm{~h}$ after the administration of tested derivatives (7a-m), in reference with phenazone and control are presented in Figure 3. and Figure 4.

Referring to the horizontal movements, the most intense negative effect was observed for $7 \mathbf{j}$ (3$\mathrm{OH}, 4-\mathrm{OCH}_{3}$ ), for which the recorded values were lower than Phenazone and Control at all three time intervals $(1 \mathrm{~h}, 2 \mathrm{~h}, 4 \mathrm{~h})$, the results being statistically significant $(p<0.05)$ in reference with Control. For example, at $4 \mathrm{~h}$ after administration, the value recorded for $7 \mathbf{j}$ was $162.8 \pm 13.8$ while the values recorded for phenazone and control were $298.6 \pm$ 24.8 and $363.0 \pm 26.1$ respectively. A slightly negative effect was observed also, at $1 \mathrm{~h}$ after administration, for $7 \mathbf{e}\left(2-\mathrm{OCH}_{3}, 299.6 \pm 21.4\right), \mathbf{7 f}$ $\left(3-\mathrm{OCH}_{3}, 253.8 \pm 23.6\right), 7 \mathbf{i}\left(3-\mathrm{NO}_{2}, 271 \pm 22.3\right), 7 \mathbf{l}$ $\left(4-\mathrm{CH}_{3}, 272.5 \pm 21.8\right)$, but the results are not statistically significant in reference with control (Figure 3). In similar conditions for $\mathbf{7 m}(2,6-\mathrm{diCl})$ it was observed a positive effect, the recorded horizontal movements being higher than phenazone and control.

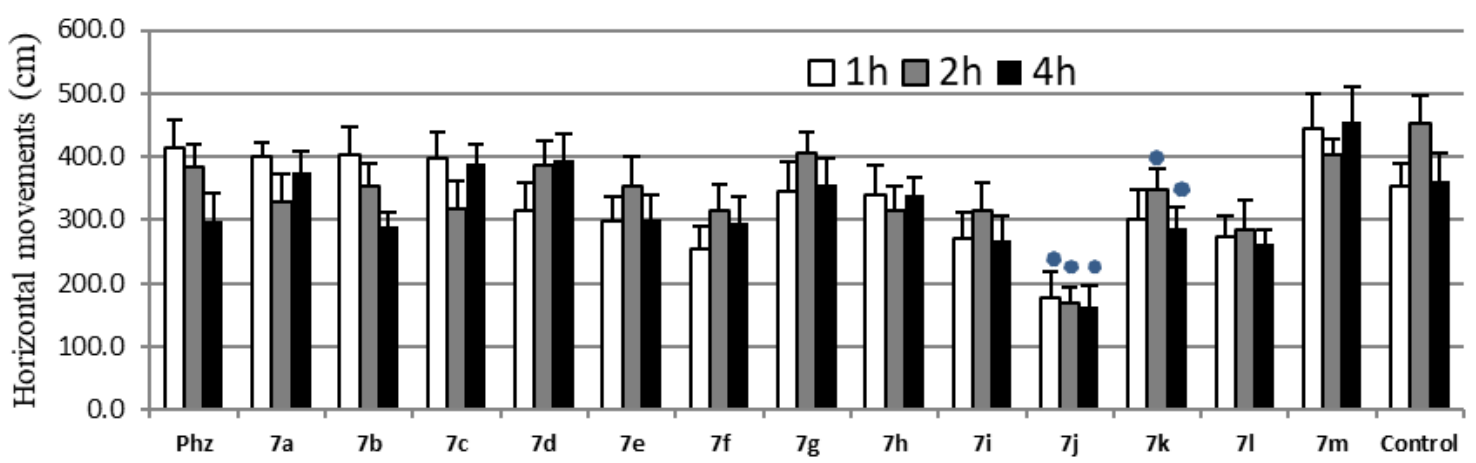

Figure 3.

The horizontal movements recorded for the tested compounds (7a-m) in reference with phenazone (Phz) and control (Tween 80$)$ groups $(\bullet p<0.05$ in reference with control)

Referring to the vertical movements the most negative effect was observed for $\mathbf{7 h}\left(2-\mathrm{NO}_{2}, 0.6 \pm 0.4\right)$ and $7 \mathbf{l}$ $\left(4-\mathrm{CH}_{3}, 1.00 \pm 0.4\right)$, the values recorded at $1 \mathrm{~h}$ after administration being 10 times and 6 times, respectively lower in reference with control $(6.1 \pm 2.5)(\mathrm{p}<0.001)$ (Figure 4). At $4 \mathrm{~h}$ after administration, an intense negative effect was observed also for $7 \mathbf{j}$ (3-OH,
$\left.4-\mathrm{OCH}_{3}, 1.4 \pm 0.7, \mathrm{p}<0.05\right), 7 \mathrm{c}(4-\mathrm{F}, 2.0 \pm 0.9, \mathrm{p}<$ $0.001), 7 \mathbf{b}(4-\mathrm{Cl}, 2.0 \pm 0.9, \mathrm{p}<0.001), 7 \mathbf{k}(4-\mathrm{OH}$, $\left.3-\mathrm{OCH}_{3}, 2.2 \pm 1.1, \mathrm{p}<0.05\right)$. For $7 \boldsymbol{a}(\mathrm{H}), 7 \mathbf{d}(4-\mathrm{Br})$, $7 \mathbf{g}\left(4-\mathrm{OCH}_{3}\right)$ and $\mathbf{7 m}(2,6-\mathrm{diCl})$, as for Phenazone, no negative influence on vertical movements was observed. 


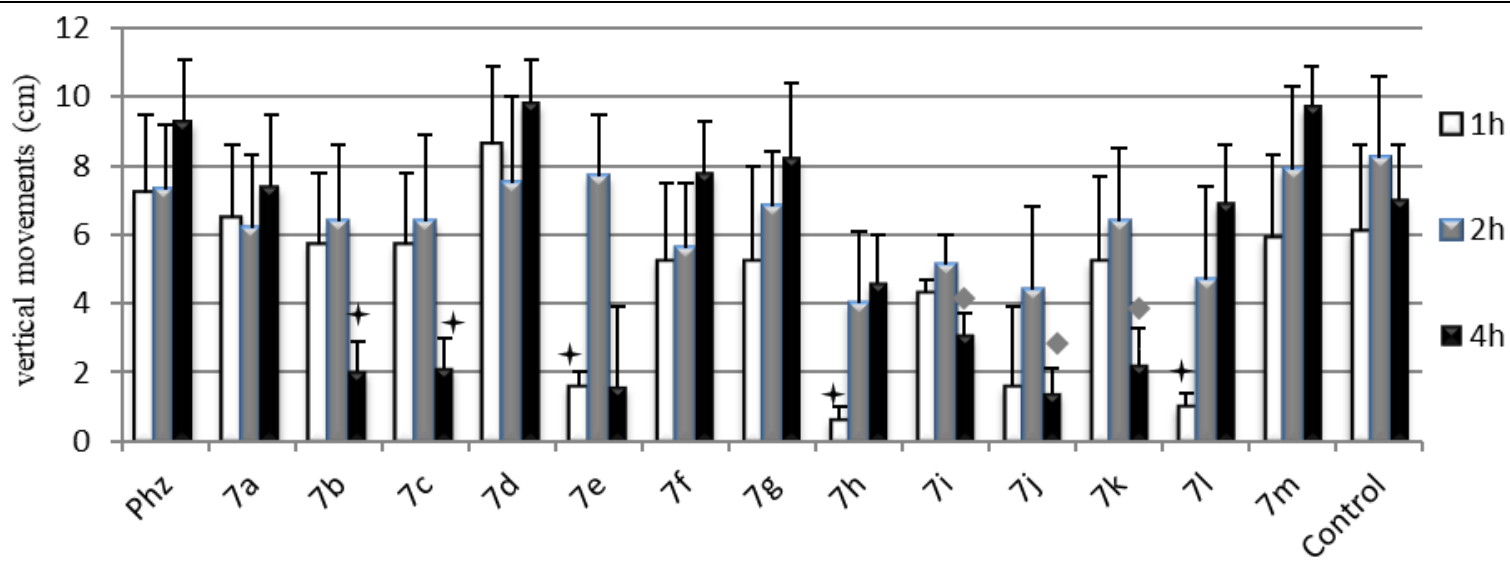

Figure 4.

The vertical movements recorded for the tested compounds (7a-m) in reference with phenazone (Phz) and control (Tween 80$)$ groups $(+\mathrm{p}<0.001, \vee \mathrm{p}<0.05$, in reference with control)

\section{Conclusions}

The toxicity degree and the effects on motor function in mice, using RotaRod performance test and assessment of spontaneous locomotor activity, of new thirteen 1,3-thiazolidine-4-ones with pyrazolone (7a-m), scaffold was evaluated. The results showed the lower toxicity of tested compounds in reference with phenazone, which supports the favourable influence of 1,3-thiazolidine-4-one moiety on pyrazolone scaffold. Based on the RotaRod performance test results it could be appreciated that the most of the tested compounds don't have neurotoxic effects because no appreciable negative influence on neuromuscular activity in mice was observed. This is also supported by the results of spontaneous locomotor activity test, counted as horizontal vertical movements of mice, when no negative effects were observed for most part of the tested compounds.

\section{References}

1. Malm H, Borisch C, Analgesics, non-steroidal antiinflammatory drugs (NSAIDs), muscle relaxants, and antigout medications, in Drugs During Pregnancy and Lactation (Third Edition), Ed. Schaefer C, Peters P, Miller R, Academic Press, 2015: 32-33.

2. Mariappan G, Saha BP, Bhuyan NR, Bharti PR, Kumar D, Evaluation of antioxidant potential of pyrazolone derivatives. $J$ Adv Pharm Technol Res., 2010; 1(2): 260-267.

3. Ahar LR, Sadr MH, Zare K, Tabatabaei SM, In vitro antimicrobial evaluation of pyrazolone derivatives. Bangladesh. J Pharmacol., 2015; 10: 143-147.

4. Wang XH, Wang XK, Liang YJ, Shi Z, Zhang JY, Chen LM, Fu LW, A cellbased screen for anticancer activity of pyrazolone derivatives. Chin J Cancer, 2010; 12: 980-987.

5. Devprakash A, Udaykumar AB A complete review of thiazolidine-4-ones. J Pharm Res., 2011; 4(7): 2436-2440.

6. Carradori S, Bizzarri B, D'Ascenzio M, De Monte C, Grande R, Rivanera D, Zicari A, Mari E, Sabatino M,
Patsilinakos A, Ragno R, Secci D, Synthesis, biological evaluation and quantitative structure-active relationships of 1,3-thiazolidin-4-one derivatives. A promising chemical scaffold endowed with high antifungal potency and low cytotoxicity. Eur J Med Chem., 2017; 140: 274-292.

7. Secci D, Carradori S, Bizzarri B, Chimenti P, De Monte C, Mollica A, Rivanera D, Zicari A, Mari E, Zengin G, Aktumsek A, Novel 1,3-thiazolidin-4one derivatives as promising anti-Candida agents endowed with anti-oxidant and chelating properties. Eur J Med Chem., 2016; 117: 144-156.

8. Drăgan M, Stan C, Pânzariu A, Jităreanu A, Profire L, New thiazolidine-4-ones of ferulic acid with antioxidant potential. Farmacia, 2015; 63(1): 150-154.

9. Živkovic MB, Matić IZ, Rodić MV, Novaković IT, Krivokuća AM, Sladić DM, Krstić NM, Anticancer potential of new steroidal thiazolidin-4-one derivatives. Mechanisms of cytotoxic action and effects on angiogenesis in vitro. J Steroid Biochem Mol Biol., 2017; 174: 72-85.

10. Bari SB, Firake SD, Exploring anti-inflammatory potential of thiazolidinone derivatives of benzenesulfonamide via synthesis, molecular docking and biological evaluation. Med Chem., 2016; 15(1): 44-53.

11. Bielenica A, Sanna G, Madeddu S, Struga M, Jóźwiak M, Kozioł AE, Sawczenko A, Materek IB, Serra A, New thiourea and 1,3-thiazolidin-4-one derivatives effective on the HIV-1 virus. Chem Biol Drug Des., 2017; 90(5): 883-891.

12. Mudgal J, Shetty P, Reddy ND, Akhila HS, Gourishetti K, Mathew G, Nayak PG, Kumar N, Kishore A, Kutty NG, Nandakumar K, Shenoy RR, Rao CM, Joseph A, In vivo evaluation of two thiazolidin-4-one derivatives in high sucrose diet fed pre-diabetic mice and their modulatory effect on AMPK, Akt and p38 MAP Kinase in L6 cells. Front Pharmacol., 2016;7: 1-10.

13. Apotrosoaei M, Vasincu I, Drăgan $\mathrm{O}$, Buron $\mathrm{F}$, Routier S, Profire L, Design, synthesis and the biological evaluation of 1,3-thiazolidine-4ones based on 4-amino-2,3-dimethyl-1-phenyl-3-pyrazolin-5one scaffold. Molecules, 2014; 19(9), 13824-13847.

14. Deora PS, Mishra CK, Mavani P, Asha R, Shrivastava $\mathrm{B}$, Rajesh KN, Effective alternative methods of $\mathrm{LD}_{50}$ 
help to save number of experimental animals. $J$ Chem Pharm Res., 2010; 2: 450-453.

15. Bonthius DJ, Winters Z, Karacav B, Bousquet SL, Bonthius DJ, Importance of genetics in fetal alcohol effects: null mutation of the nNOS gene worsens alcohol-induced cerebellar neuronal losses and behavioral deficits. Neurotoxicology, 2015; 46: 60-72.

16. Carter RJ, Morton AJ, Dunnett SB, Motor coordination and balance in rodents. Curr Protoc Neurosci., 2001; Chapter 8: Unit 8. 12.

17. Rusu G, Lupusoru CE, Mititelu-Tartau L, Popa G, Bibire N, Lupusoru RV, Cristofor AC, Nechifor M, Effects of two imidazoline receptor antagonists in spontaneous behaviour in rats. Farmacia, 2015; 63(2): 2016-2010.
18. Lynch JJ, Castagné V, Moser PC, Mittelstadt SW, Comparison of methods for the assessment of locomotor activity in rodent safety pharmacology studies. J Parmacol Toxicol Methods, 2011; 64 (1): 74-80.

19. Dănilă G, Cotrău M, Nechifor M, Toxicological gata guide, București, Ed. Medicală, 1984 (available in Romanian).

20. Sestakova N, Puzserova A, Kluknavsky M, Bernatova I., Determination of motor activity and anxietyrelated behaviour in rodents: methodological aspects and role of nitric oxide. Interdiscip Toxicol., 2013; 6(3): 126-135. 